\title{
Determination of Molecular Weights of Dextrans by Means of Alkaline Copper Reagents ${ }^{1}$
}

\author{
H. S. Isbell, C. F. Snyder, N. B. Holt, and M. R. Dryden
}

\begin{abstract}
Reducing values were determined for samples of clinical dextrans, gentiobiose, and isomaltose with several alkaline copper reagents. The results for the dextrans were converted to number-average molecular weights on the assumption that equimolecular quantities of dextran, isomaltose, and gentiobiose have approximately the same reducing power. The molecular weights, thus obtained, are in fair agreement with values obtained by the recently developed radioactive cyanide method. The results show that copper-reducing methods are suitable for the determination of the number-average molecular weights of clinical dextrans.
\end{abstract}

\section{Principles of the Method}

There is widespread interest in degraded dextrans prepared from material formed by the action of Leuconostoc mesenteroides and other bacterial agents on sucrose. Various fractions of these carbohydrates are under investigation as blood-plasma extenders. Therefore, simple and reliable methods of analysis of these clinical products are desirable. Dextran is composed of glucose units in 1,6-glycosidic linkage, with occasional branching at carbons 3 or 4 $[1,2,3,4] .^{2}$ The terminal reducing unit consists of a glucose molecule substituted at carbon 6 with an alpha glucosyl group. Ordinarily, each molecule of clinical dextran has one, and only one, reducing end group. This condition arises from the manufacturing process, which ordinarily involves hydrolytic cleavage of a high-molecular-weight polysaccharide [5]. Each cleavage results in two molecules. One contains the reducing end group originally present; the other contains the reducing end group formed by cleavage of a glycosidic link. Thus there is one reducing group per molecule, and the numberaverage molecular weight ${ }^{3}$ can be calculated from the number of reducing groups per unit weight.

The reducing end groups are largely responsible for the capacity of the polysaccharide to reduce alkaline copper and other reagents. For determination of reducing groups in polysaccharides of relatively low molecular weight, alkaline copper reagents, iron salts, and dinitrosalicylic acid have been most widely used. These reagents do not react stoichiometrically, and factors must be derived for converting the reducing values to molecular weight. For the determination of the molecular weights of starches, Meyer, Noelting, and Bernfeld [6] applied Sumner's dinitrosalicylic acid method and standardized the results with maltose. The reducing end group of dextran differs from that of starch in that it has a 1,6- $\alpha$ glucosyl link in place of a 1,4- $\alpha$-glucosyl link. Isbell, Pigman, and Frush [7] have shown that the position and the configuration of the gluco-

\footnotetext{
1 This work was supported, in part, by the Medical Research and Development Board, Office of The Surgeon General, Department of the Army. It was carried out under the Plasma Volume Expanders Program of the Subwas carried out under the Plasma Volume Expanders Program of the Subby the Office of the Surgeon General, U. S. Department of the Army.

2 Figures in brackets indicate the literature references at the end of this paper.

3 The number-average molecular weight, $M_{n}=\Sigma\left(n_{i} M_{i}\right) / \Sigma n_{i}$, where $n_{i}$ is the number of molecules of molecular weight $M_{i}$.
}

sidic link in a disaccharide influences the molecular reducing power, and that a parallelism exists in the molecular reducing power of substances of the same or similar structure. The reducing power per molecule of a disaccharide having a 1,6-link is substantially higher than that of the corresponding monosaccharide. Presumably the higher reduction arises from cleavage of the disaccharide link in the partially oxidized product during the analysis with alkaline copper reagents. Glycosidic links in polysaccharides near the reducing groups would be broken more readily than links one or more hexose units removed from the reducing end group. For this reason the hexose units more than one unit removed from the reducing end group would not contribute appreciably to the reducing power, and a molecule of dextran should have the same reducing power as a molecule of isomaltose. Thus the molecular weight of a clinical dextran might be calculated from the reducing power of isomaltose (6- $\alpha$-D-glucopyranosylD-glucose). Isomaltose has not been crystallized, and the amorphous material available is of doubtful purity. Therefore, for most of the comparisons given in this paper and those given in [8] and [9], the closely related substance, gentiobiose, (6- $\beta$-Dglucopyranosyl-D-glucose) was selected as a reference standard, even though it has the beta linkage rather than the alpha linkage common to dextran and isomaltose.

In the present study copper-reducing values were measured for samples of clinical dextrans and gentiobiose by several methods, and the number-average molecular weights of the dextrans were calculated on the postulate that a molecule of dextran has the same reducing power as a molecule of gentiobiose. Table 1 gives the molecular weights thus obtained, together with those estimated by the recently developed radioactive cyanide method [10]. The results obtained by different copper-reducing methods are in fair agreement with one another and with those obtained by the cyanide method. The results show the practicability of determining numberaverage molecular weights by copper-reducing methods, but further refinements in the method seemed desirable.

Following the suggestion of one of us [8] that equimolecular quantities of dextran and isomaltose 
TABLE 1. Comparison of number-average molecular weights of dextrans obtained by various methods, using gentiobiose as a standard

\begin{tabular}{|c|c|c|c|c|c|c|c|c|c|c|c|}
\hline Sample & Scales & $d$ a & $\begin{array}{c}\text { Somogyi } \\
\mathrm{PO}_{4}\end{array}$ & $d^{\text {a }}$ & $\begin{array}{c}\text { Somogyi } \\
\mathrm{CO}_{3}\end{array}$ & $d^{\text {a }}$ & Folin-Wu & $d^{\mathrm{s}}$ & $\mathrm{HCN}$ & $d$ a & Mean \\
\hline $\begin{array}{l}1 \\
2 \\
3 \\
4 \\
5\end{array}$ & $\begin{array}{l}45,600 \\
42,000 \\
40,700 \\
36,700 \\
33,600\end{array}$ & $\begin{array}{l}+3.64 \\
-2.78 \\
+1.75 \\
+3.09 \\
-1.75\end{array}$ & $\begin{array}{l}44,100 \\
45,300 \\
40,300 \\
35,500 \\
34,700\end{array}$ & $\begin{array}{l}+0.23 \\
+4.86 \\
+0.75 \\
-0.28 \\
+1.46\end{array}$ & $\begin{array}{l}40,800 \\
40,900 \\
40,900 \\
32,800 \\
31,600\end{array}$ & $\begin{array}{l}-7.27 \\
-5.32 \\
+2.25 \\
-7.87 \\
-7.60\end{array}$ & $\begin{array}{l}43,900 \\
46,100 \\
36,200 \\
35,300\end{array}$ & $\begin{array}{l}-0.23 \\
+6.71 \\
+1.69 \\
+3.22\end{array}$ & $\begin{array}{l}45,800 \\
41,600 \\
38,200 \\
36,600 \\
35,700\end{array}$ & $\begin{array}{l}+4.09 \\
-3.70 \\
-4.50 \\
+2.81 \\
+4.39\end{array}$ & $\begin{array}{l}44,000 \\
43,200 \\
40,000 \\
35,600 \\
34,200\end{array}$ \\
\hline $\begin{array}{l}6 \ldots \ldots \ldots \\
7 \\
8 \\
9 \\
10\end{array}$ & $\begin{array}{l}73,600 \\
33,800 \\
19,200 \\
30,500 \\
33,600\end{array}$ & $\begin{array}{l}-0.14 \\
+1.20 \\
-1.54 \\
-2.24 \\
-4.82\end{array}$ & $\begin{array}{l}34,900 \\
20,200 \\
32,000 \\
36,500\end{array}$ & $\begin{array}{l}+4.49 \\
+3.59 \\
+2.56 \\
+3.40\end{array}$ & $\begin{array}{l}71,700 \\
31,400 \\
17,700 \\
29,700 \\
35,700\end{array}$ & $\begin{array}{l}-2.71 \\
-5.99 \\
-9.23 \\
-4.81 \\
+1.13\end{array}$ & $\begin{array}{l}76,400 \\
20,900 \\
32,500\end{array}$ & $\begin{array}{l}+3.66 \\
+7.18 \\
+4.17 \\
\end{array}$ & $\begin{array}{l}73,000 \\
\cdots \\
\cdots\end{array}$ & \begin{tabular}{l}
-0.95 \\
\hdashline-1. \\
-1.
\end{tabular} & $\begin{array}{l}73,700 \\
33,400 \\
19,500 \\
31,200 \\
35,300\end{array}$ \\
\hline $11 \ldots$ & 33,600 & -1.47 & 33,900 & -0.59 & 34,700 & +1.76 & ....... & ...... & -..... & -..... & 34,100 \\
\hline A verage - & & -0.46 & -..... & +2.05 & (...... & -4.15 & -..... & +3.77 & - & +0.36 & \\
\hline
\end{tabular}

a Percentage deviation from arithmetic mean.

have like reducing powers, workers in other laboratories developed analytical procedures based on an isomaltose standard. A group at the Commercial Solvents Corp. applied Somogyi's method [11] to dextran and isomaltose. With a 20-min heating period they found that $1 \mathrm{ml}$ of $0.005 \mathrm{~N}$ copper reagent is equivalent to $0.222 \mathrm{mg}$ (or 0.000649 millimoles) of isomaltose [12]. Recently, the Northern Regional Research Laboratory, U. S. Department of Agriculture, kindly furnished us a sample of substantially pure but amorphous isomaltose. A study with the Somogyi phosphate method revealed that the reducing power of this sample of isomaltose was only 94 percent that of gentiobiose. A lower reducing power for the disaccharide having the alpha configuration is in accord with the relative reducing power of maltose and cellobiose. Because dextran and isomaltose have the alpha glucoside structure, whereas gentiobiose has the beta structure, isomaltose would be preferred as a reference compound. Nevertheless, one hesitates to standardize a method on an amorphous sugar. For this reason, it seems desirable to select an arbitrary factor until pure crystalline isomaltose is generally available for use in standardization. The average of our values for the reduction equivalents of isomaltose and gentiobiose is 0.00065 millimole of sugar for each milliliter of $0.005 N$ reagent. This is close to that obtained by the group at Commercial Solvents Corp. for isomaltose. Use of this figure gives the following equation for converting copper-reducing values obtained by the Somogyi method to molecular weight: $M_{n}=w /(V \times 0.00065)$, where $M_{n}$ is the numberaverage molecular weight of the dextran, $w$ is the weight of sample in milligrams, and $V$ is the net titration in milliliters of $0.005 \mathrm{~N}$ solution.

\section{Experimental Procedures}

\subsection{Preparation of Samples}

a. Gentiobiose

Gentiobiose methyl alcoholate was prepared by the method described on page 463 of reference 13 . The alcoholate was converted to the pure anhydrous beta modification of sugar by dissolution in water, followed by evaporation of the water and alcohol under reduced pressure. The resulting sirup crystallized spontaneously. The material was recrystallized by dissolving in water, concentrating the solution to about 90 -percent total solids, adding 5 parts of methyl cellosolve, and seeding with $\beta$-Dgentiobiose crystals. The crystals that formed were separated, washed with methyl cellosolve, and dried under reduced pressure at $60^{\circ} \mathrm{C}$. At equilibrium $[\alpha]_{D}^{20}$ was found to be +9.60 (water, $\left.\mathrm{C}=2\right)^{4}$ in agreement with the reported value of +9.6 .

\section{b. Isomaltose}

The 1somaltose was supplied by Allene Jeanes of the Northern Regional Research Laboratory. It was a carefully purified amorphous sample originally prepared from the octaacetate. It contained by analysis 41.1 percent of carbon and 6.6 percent of hydrogen. The carbon content corresponds to a product containing 97.6 percent of the anhydrous disaccharide. Hence the dry weight of the material used for the determination of reducing power was based on the assumption that the material contained 2.4 percent of moist re.

\section{c. Dextran samples}

The samples of clinical dextran received in powdered form were dissolved in water, filtered, and lyophilized (freeze dried). Dextran received in "saline" solution was purified by two precipitations with methanol. The resulting material was dissolved in water, filtered, and lyophilized. For the analytical measurements lyophilized samples were placed in tared volumetric flasks and dried to constant weight at room temperature under less than $0.1-\mathrm{mm} \mathrm{Hg}$ pressure in a desiccator connected with a dry-ice-acetone trap. After the weight of the dry sample had been determined, water was added and the solution was made to volume. For the analyses, suitable quantities of the solution were transferred with a pipette to the reaction tubes or flasks.

\subsection{Modified Scales Method}

The reagents and procedure were the same as those given on page 189 of reference 13 , except that a

\footnotetext{
${ }^{4} 2$ grams of gentiobiose dissolved in water and made up to $100 \mathrm{ml}$.
} 
TABLE 2. Reducing values of gentiobiose by the modified Scales method $[\gamma]$

(10-min boiling time)

\begin{tabular}{|c|c|c|c|}
\hline Sample & $\begin{array}{c}\text { Net titra- } \\
\text { tion } 0.04 \\
N \text { iodine }\end{array}$ & \multicolumn{2}{|c|}{ Sugar/ml of titration } \\
$m g$ & $m l$ & $m g$ & Millimoles \\
9.93 & 5.98 & 1.661 & 0.00485 \\
14.98 & 8.94 & 1.676 & .00490 \\
19.86 & 11.78 & 1.686 & .00493 \\
24.91 & 14.64 & 1.702 & .00497 \\
29.96 & 17.39 & 1.723 & .00503 \\
& & & \\
\hline & & & \\
\hline
\end{tabular}

10-min boiling time was used in place of $6 \mathrm{~min}$. The reduction values found for gentiobiose are given in table 2.

With samples of gentiobiose the reducing power changed with concentration. Hence a curve was made by plotting the millimoles gentiobiose per milliliter of $0.04 N$ reagent with respect to the net titration in milliliters. Readings from this curve were used as factors to convert the net titrations obtained with dextran samples to gentiobiose equivalents. The following formula was used to convert the results obtained with clinical dextran to molecular weights: $M_{n}=w /(V \times f)$, where $w$ is the weight of sample in milligrams, $f$ is the millimoles of gentiobiose equivalent to each milliliter of the titration read from the curve, and $V$ is the net titration in milliliters of $0.04 N$ solution. Some results obtained with clinical dextran samples are given in table 3.

TABLE 3. Number-average molecular weights of clinical dextrans obtained with modified Scales method

(Boiling time 10-min; total heating period $14 \mathrm{~min}$

\begin{tabular}{|c|c|c|c|c|}
\hline $\begin{array}{c}\text { Dextran sample } \\
\text { number }\end{array}$ & $\begin{array}{l}w \text {, weight } \\
\text { of sample }\end{array}$ & $\begin{array}{c}V, \text { net } \\
\text { titration } \\
0.04 N \\
\text { solution }\end{array}$ & $\begin{array}{l}f, \text { milli- } \\
\text { moles of } \\
\text { zentiobiose } \\
\text { per milli- } \\
\text { liter }\end{array}$ & $M_{n}$ \\
\hline & & & & \\
\hline $\mathrm{L}-1 \ldots$ & $\begin{array}{l}977.0 \\
9780\end{array}$ & $\begin{array}{l}10.37 \\
10.44\end{array}$ & $\begin{array}{r}0.00491 \\
00402\end{array}$ & $\begin{array}{l}19,200 \\
19,00\end{array}$ \\
\hline B-742 & 1001.8 & 6. 10 & .00486 & $\begin{array}{l}15,800 \\
33,800\end{array}$ \\
\hline & 982.6 & 6. 00 & .00484 & 33,800 \\
\hline $\mathrm{R}-2$ & & 6. 64 & .00486 & 30,500 \\
\hline $84649 \mathrm{~A}$ & $\begin{array}{l}91.0 \\
981.2\end{array}$ & $\begin{array}{l}6.61 \\
4.47\end{array}$ & $\begin{array}{r}00486 \\
.00483\end{array}$ & $\begin{array}{l}30,400 \\
45,400\end{array}$ \\
\hline $84657 \mathrm{~A}$ & 995.1 & 4.47 & .00483 & 46,100 \\
\hline $84668 \mathrm{~A}$ & 1013. 4 & 4.5 & .00483 & 45,900 \\
\hline & 881.2 & 4. 98 & .00484 & 36,600 \\
\hline S-155 . . & $\begin{array}{r}1026.3 \\
9840\end{array}$ & 6. 33 & $\begin{array}{l}.00486 \\
00485\end{array}$ & 33,400 \\
\hline $\mathrm{CsC} 275$ & 1004.4 & 6. 19 & .00486 & 33,400 \\
\hline & & 6. 0 & .004 & 33.500 \\
\hline $\mathrm{CSC} 281$ & 1002.6 & 6. 07 & .00485 & 34,000 \\
\hline & 1000.0 & 6. 22 & .00486 & 32,100 \\
\hline NBS & $\begin{array}{l}1032.1 \\
1033.3\end{array}$ & 5. 24 & .00484 & 40,700 \\
\hline
\end{tabular}

\subsection{Somogyi Phosphate Method}

The procedure and reagents used were essentially the same as those described by Somogyi [11] but are repeated in part, since the original article gives certain alternative procedures.

The alkaline copper reagent was prepared from $70.6 \mathrm{~g}$ of $\mathrm{Na}_{2} \mathrm{HPO}_{4} .12 \mathrm{H}_{2} \mathrm{O}, 40 \mathrm{~g}$ of Rochelle salt, 100 $\mathrm{ml}$ of $\mathrm{N} \mathrm{NaOH}$ solution, and $80 \mathrm{ml}$ of solution containing $8 \mathrm{~g}$ of $\mathrm{CuSO}_{4} .5 \mathrm{H}_{2} \mathrm{O}, 180 \mathrm{~g}$ of $\mathrm{Na}_{2} \mathrm{SO}_{4}$, and water to make 1 liter. For some of the measurements a measured volume of the sugar solution was heated with an equal volume of the copper-phosphate solution. After cooling, a precisely measured amount of a standard potassium iodate solution and an appropriate amount of potassium iodide and sulfuric acid was added, and after complete oxidation of the cuprous copper the residual free iodine was titrated with $0.005 N$ sodium thiosulfate. In other measurements the "combined" copper reagent was used. This reagent is prepared by incorporation of the requisite quantity of potassium iodate in the alkaline copper solution. Two concentrations were used; one contained $2 \mathrm{ml}$ and the other $1 \mathrm{ml}$ of $N$ potassium iodate per $100 \mathrm{ml}$ of the combined copper reagent.

The analyses were made in $25 \times 250$-mm test tubes in groups of eight. Five-milliliter quantities of the solutions containing from 0.002 to 0.01 millimoles of gentiobiose, isomaltose, or dextran, or $5 \mathrm{ml}$ of water for blank measurements, were transferred to the test tubes. Each sample was mixed with $5 \mathrm{ml}$ of the copper reagent. When the "combined" reagent was employed, its volume was measured precisely. The tubes were closed with funnel-shaped stoppers and placed in a rack suspended in a boiling-water bath. After $25 \mathrm{~min}$ the rack and tubes were transferred to a cold-water bath and brought to room temperature. The tubes were then treated separately and successively. In measurements using the unmodified copper reagent a precisely measured volume of $0.01 \mathrm{~N}$ $\mathrm{KIO}_{3}$ was pipetted into the tube; in those made with the "combined" alkaline copper reagent this step was omitted, since the reagent already contained the necessary potassium iodate. In any case, the sides of the tube were washed down with 1 or $2 \mathrm{ml}$ of 2.5-percent potassium iodide without agitation to minimize oxidation by air. Immediately following the addition of potassium iodide, $1.5 \mathrm{ml}$ of $2 \mathrm{~N} \mathrm{H}_{2} \mathrm{SO}_{4}$ was added with shaking, so that the contents of the tube were mixed quickly and acidified. When all the cuprous oxide was dissolved the excess iodine was titrated with $0.005 \mathrm{~N}$ sodium thiosulfate and a starch indicator. The titer of the sample subtracted from the titer of the blank containing a like quantity of potassium iodate is the net titration. This corresponds to the reducing sugar present.

Prior to the selection of a heating period of 25 min, the effect of boiling time on the reaction was studied. The measurements reported in table 4

TABLE 4. Effect of the length of the heating period on reduction of 2-mg samples of gentiobiose by the Somogyi phosphate method

[Combined copper-iodate solution]

\begin{tabular}{|c|c|c|}
\hline $\begin{array}{c}\text { Time of } \\
\text { boiling }\end{array}$ & $\begin{array}{c}\text { Net } \\
\text { titration } \\
0.005 \mathrm{~N} \\
\text { thiosulfate }\end{array}$ & $\begin{array}{c}\text { Milligram of } \\
\text { gentiobiose } \\
\text { per milliliter } \\
\text { of net } \\
\text { titration }\end{array}$ \\
min & $m l$ & \\
55 & 7.38 & 0.271 \\
7.5 & 8.24 & .243 \\
10 & 9.10 & .220 \\
12.5 & 9.22 & .217 \\
15 & 9.23 & .217 \\
20 & 9.38 & .213 \\
25 & 9.50 & .211 \\
30 & 9.42 & .212 \\
& & \\
& & \\
\hline
\end{tabular}


show that the amount of reduction is substantially constant after $20 \mathrm{~min}^{5}$

The results obtained by the Somogyi-phosphate method with gentiobiose and isomaltose are given in tables 5 and 6 . The amount of reduction was found to be roughly proportional to the amount of sugar, in the range covered by net titrations from 6 to 13 $\mathrm{ml}$. Smaller samples gave slightly lower factors and larger samples higher factors. For this reason the weights of the dextran samples were adjusted to give titrations of from 6 to $13 \mathrm{ml}$, and the same factor was used for all samples. The results obtained with clinical dextrans, using a 25 -min heating period, are given in table 7 . The molecular weights based on the gentiobiose standard were obtained by the formula

$$
M_{n}=\frac{w}{V \times 0.216 / 342.3}=\frac{w}{V \times 0.000631}
$$

in which $M_{n}$ is the number-average molecular weight, $w$ is the weight of the sample in milligrams, $V$ is the net titration in milliliters of $0.005 \mathrm{~N}$ reagent, and 0.000631 is the reduction equivalent of dextran expressed in millimoles per milliliter of reagent. Multiplication of the results by 0.939 gives values based on isomaltose, and multiplication by 0.969 gives values based on an empirical factor that is the mean of the values found for isomaltose and gentiobiose. This empirical factor is in agreement with a value found by Commercial Solvents Corp. for isomaltose.

TABLE 5. Reduction equivalents by the Somogyi phosphate reagent determined with gentiobiose

\begin{tabular}{|c|c|c|}
\hline $\begin{array}{c}\text { Sample } \\
\text { gentiobiose }\end{array}$ & $\begin{array}{l}\text { Net } \\
\text { titration } \\
0.005 \mathrm{~N} \\
\text { solution }\end{array}$ & $\begin{array}{l}\text { Milligram of } \\
\text { sugar per } \\
\text { milliliter of } \\
\text { titration }\end{array}$ \\
\hline \multicolumn{3}{|c|}{ Separate addition of iodate } \\
\hline $\begin{array}{l}m g \\
1.2 \\
1.4 \\
1.8 \\
1.8 \\
2.2\end{array}$ & $\begin{array}{c}m l \\
5.80 \\
6.66 \\
8.47 \\
8.49 \\
10.28\end{array}$ & $\begin{array}{l}0.207 \\
.210 \\
.213 \\
.212 \\
.214\end{array}$ \\
\hline $\begin{array}{l}\text { 2. } 2 \\
2.2 \\
2.6 \\
2.6 \\
2.6\end{array}$ & $\begin{array}{r}9.55 \\
10.25 \\
12.09 \\
12.06 \\
12.06\end{array}$ & $\begin{array}{l}.230 \\
.215 \\
.215 \\
.216 \\
.216\end{array}$ \\
\hline $\begin{array}{l}\text { 3. } 0 \\
3.0 \\
3.0\end{array}$ & $\begin{array}{l}13.60 \\
13.70 \\
13.67\end{array}$ & $\begin{array}{l}.221 \\
.219 \\
.219\end{array}$ \\
\hline \multicolumn{2}{|l|}{ Mean... } & 0.216 \\
\hline \multicolumn{3}{|c|}{$\begin{array}{l}\text { Combined copper and iodate } \\
\text { solution }\end{array}$} \\
\hline $\begin{array}{l}1.0 \\
1.5 \\
2.0 \\
2.5 \\
3.0\end{array}$ & $\begin{array}{r}4.63 \\
6.95 \\
9.39 \\
11.53 \\
13.62\end{array}$ & $\begin{array}{r}0.216 \\
.216 \\
.213 \\
.217 \\
.220\end{array}$ \\
\hline \multicolumn{2}{|l|}{ Mean.- } & 0.216 \\
\hline
\end{tabular}

From a somewhat similar study [12] the group at C.S.C. selected a heating period of $20 \mathrm{~min}$.
TABLE 6. Reduction equivalents of the Somogyi combined copper phosphate-iodate reagent determined with isomaltose

(25-min boiling time)

\begin{tabular}{|c|c|c|}
\hline Isomaltose & $\begin{array}{l}\text { Net } \\
\text { titration } \\
0.0005 \mathrm{~N} \\
\text { solution }\end{array}$ & $\begin{array}{l}\text { Milligram of } \\
\text { isomaltose } \\
\text { per milliliter } \\
\text { net titration }\end{array}$ \\
\hline $\begin{array}{c}m g \\
0.567 \\
1.133 \\
1.700 \\
2.267 \\
2.834\end{array}$ & $\begin{array}{r}m l \\
2.52 \\
4.89 \\
7.17 \\
9.92 \\
12.55\end{array}$ & $\begin{array}{r}0.225 \\
.232 \\
.237 \\
.229 \\
.226\end{array}$ \\
\hline A verage & & 0.230 \\
\hline
\end{tabular}

TABLE 7. Number-average molecular weights of clinical dextrans determined by the Somogyi phosphate method (gentiobiose standard)

(Heating time $25 \mathrm{~min}$ )

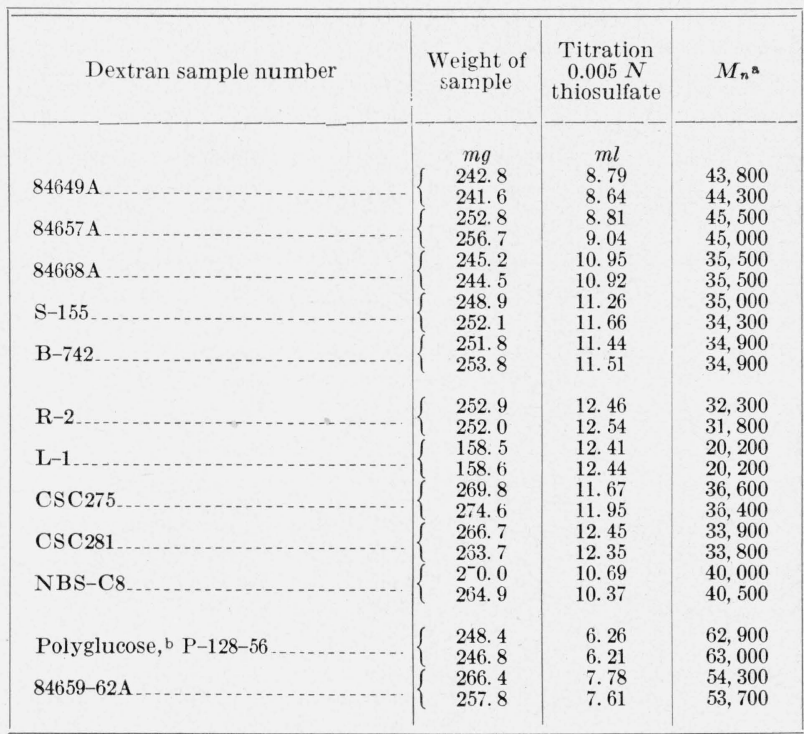

a $M_{n}=w /(V \times 0.000631)$.

b This substance, a polysaccharide prepared by chemical means, is included, even though it is not a true dextran.

\subsection{Somogyi Carbonate Method [14]}

Reagents and procedure were the same as those given in reference 15 , except that a $30-\mathrm{min}$ heating time was used.

The procedure was standardized by use of definite amounts of gentiobiose. Because the reduction equivalents, given in table 8 , did not show any definite trend with change in concentration, the average reduction equivalent was used rather than a separate factor for each titration value. That is $1 \mathrm{ml}$ of 0.005 $N$ thiosulfate was found, on the average, to be equivalent to $0.214 \mathrm{mg}$ of gentiobiose. Some results obtained with dextran samples are given in table 9 . The number-average molecular weights were obtained from the formula $M_{n}=w /(V \times 0.000625)$, in which $w$ is the weight of the dextran sample in milligrams, and $V$ is the net titration in milliliters of $0.005 N$ thiosulfate. 
TABLE 8. Somogyi carbonate method Reduction equivalents of varying amounts of gentiobiese $(30-$ min heating period)

\begin{tabular}{|c|c|c|}
\hline Gentiobiose & $\begin{array}{l}\text { Net titra- } \\
\text { tion } 0.005 \mathrm{~N} \\
\text { thiosulfate }\end{array}$ & $\begin{array}{l}\text { Milligram of } \\
\text { gentiobiose } \\
\text { per milliliter } \\
\text { of } 0.005 \mathrm{~N} \\
\text { solution }\end{array}$ \\
\hline $\begin{array}{c}m g \\
\text { 1. } 2434 \\
2.4869 \\
2.4868 \\
\text { 2. } 7977 \\
\text { 3. } 1085\end{array}$ & $\begin{array}{r}6.03 \\
11.43 \\
11.73 \\
12.42 \\
14.21\end{array}$ & $\begin{array}{r}0.206 \\
.218 \\
.212 \\
.225 \\
.219\end{array}$ \\
\hline $\begin{array}{l}\text { 1. } 1389 \\
\text { 1. } 7084 \\
\text { 2. } 2779 \\
\text { 2. } 8473 \\
\text { 2. } 8473\end{array}$ & $\begin{array}{r}5.22 \\
8.27 \\
11.02 \\
13.10 \\
\text { 13. } 13\end{array}$ & $\begin{array}{l}.218 \\
.207 \\
.207 \\
.217 \\
.217\end{array}$ \\
\hline $\begin{array}{l}\text { 1. } 1389 \\
\text { 1. } 2470 \\
\text { 1. } 8705 \\
\text { 2. } 4940\end{array}$ & $\begin{array}{r}5.25 \\
5.73 \\
9.06 \\
11.73\end{array}$ & $\begin{array}{l}.217 \\
.218 \\
.206 \\
.213\end{array}$ \\
\hline Mean & & 0.214 \\
\hline
\end{tabular}

TABLE 9. Number-average molecular weights of clinical dextrans determined by the Somogyi carbonate method [14]

(Heating time $30 \mathrm{~min}$ )

\begin{tabular}{|c|c|c|c|}
\hline Dextran sample number & $\begin{array}{l}\text { Weight of } \\
\text { sample }\end{array}$ & $\begin{array}{c}\text { Titration } \\
0.005 \mathrm{~N} \\
\text { thiosulfate }\end{array}$ & $M_{n}{ }^{8}$ \\
\hline $\begin{array}{l}84649 \mathrm{~A} \\
84657 \mathrm{~A} \\
84668 \mathrm{~A} \\
\mathrm{~S}-155 \\
\mathrm{~B}-50074\end{array}$ & $\begin{array}{r}m g \\
287.5 \\
286.6 \\
310.5 \\
302.0 \\
281.5 \\
274.3\end{array}$ & $\begin{array}{r}m l \\
11.27 \\
11.21 \\
15.16 \\
15.90 \\
13.72 \\
6.12\end{array}$ & $\begin{array}{l}40,800 \\
40,900 \\
32,800 \\
30,400 \\
32,800 \\
71,700\end{array}$ \\
\hline $\begin{array}{l}\mathrm{L}-1 \\
\mathrm{R}-2 \\
\mathrm{~N}-742 \mathrm{C}-2 \\
\mathrm{NRC} 3\end{array}$ & $\left\{\begin{array}{r}148.1 \\
147.6 \\
288.7 \\
99.0 \\
99.0 \\
197.2 \\
204.0\end{array}\right.$ & $\begin{array}{r}13.40 \\
7.95 \\
14.71 \\
12.07 \\
12.06 \\
7.30 \\
7.64\end{array}$ & $\begin{array}{l}17,700 \\
29,700 \\
31,400 \\
13,100 \\
13,100 \\
43,200 \\
42,700\end{array}$ \\
\hline $\begin{array}{l}\text { NRC-4 } \\
84657 \mathrm{~A} \\
\mathrm{CSC} 275 \\
\mathrm{CSC} 281 . . . \\
\text { NBS-C8 }\end{array}$ & $\left\{\begin{array}{l}186.0 \\
202.6 \\
274.5 \\
270.4 \\
276.2 \\
266.0 \\
268.2 \\
267.9 \\
268.3 \\
270.2\end{array}\right.$ & $\begin{array}{r}4.16 \\
4.62 \\
10.45 \\
10.30 \\
12.60 \\
11.70 \\
12.40 \\
12.32 \\
10.35 \\
10.76\end{array}$ & $\begin{array}{l}71,500 \\
70,200 \\
42,000 \\
42,000 \\
35,100 \\
36,400 \\
31,600 \\
34,800 \\
41,500 \\
40,200\end{array}$ \\
\hline $\begin{array}{l}\mathrm{NRC}-2 \mathrm{~b} \\
\mathrm{NRC}-2\end{array}$ & $\left\{\begin{array}{l}89.1 \\
90.3 \\
97.1 \\
96.5\end{array}\right.$ & $\begin{array}{l}10.25 \\
10.23 \\
10.95 \\
10.78\end{array}$ & $\begin{array}{l}13,900 \\
14,100 \\
14,200 \\
14,300\end{array}$ \\
\hline
\end{tabular}

a $M_{n}=\mathrm{W} /(V \times 0.000625)$

b Reclaimed from sample NRC-2 after dissolution in water, precipitation with methanol, dissolution again in water, treated with vegetable char, filtered, and the filtrate lyophilion a

the filtrate lyophilized.
- Same as NRC-2-A, except no char treatment was used in its preparation.

\subsection{Folin-Wu Method [16]}

The method of Folin and Wu was studied with the view that it might be useful for routine determinations in the hands of laboratory technicians. The procedure was essentially that described on page 198 of reference 17. The color measurements were made with both Klett-Summerson and Lumetron photoelectric colorimeters. As with other microreducing sugar methods, it is essential that the analyst standardize his procedure by measurements of the reducing power of a series of standards covering the range to be used. Table 10 gives some results obtained with anhydrous dextrose and gentiobiose.

TABLE 10. Percentage of transmission of typical standards
for the Folin and $W u$ method mission of blank is 100)

\begin{tabular}{|c|c|c|c|}
\hline \multicolumn{2}{|c|}{ Dextrose } & \multicolumn{2}{|c|}{ Gentiobiose } \\
\hline $\begin{array}{l}\text { Milligrams } \\
\text { of sugar in } \\
100 \text { milliliters }\end{array}$ & $\begin{array}{l}\text { Transmis- } \\
\text { sion }\end{array}$ & $\begin{array}{l}\text { Milligrams } \\
\text { of sugar in } \\
100 \text { milliliters }\end{array}$ & $\begin{array}{l}\text { Transmis- } \\
\text { sion }\end{array}$ \\
\hline $\begin{array}{l}5 \\
7.5 \\
10 \\
15 \\
20 \\
25 \\
30\end{array}$ & $\begin{array}{c}\text { Percent } \\
85.2 \\
78.5 \\
70.3 \\
57.2 \\
46.5 \\
37.7 \\
31.1\end{array}$ & $\begin{array}{l}10.5 \\
17.1 \\
25.0 \\
34.2 \\
42 \\
50 \\
\ldots\end{array}$ & $\begin{array}{c}\text { Percent } \\
86.5 \\
73.4 \\
63.7 \\
51.0 \\
41.3 \\
35.6 \\
\ldots\end{array}$ \\
\hline
\end{tabular}

In the analysis of dextrans, a standard, ordinarily gentiobiose, was always included in each set of determinations. Thus, the small variation in reducing power from one set to another, as well as from day to day, is compensated for by the application of suitable corrections. The dextrose equivalent or the gentiobiose equivalent for dextran is then obtained by calculation, or by graphic means. It has been our experience that it is desirable to employ standards yielding a transmission reading close to that obtained for the dextran under analysis. Some values obtained by this method are included in table 1.

The authors express their appreciation to the National Research Council and to the Office of the Surgeon General for their support and cooperation in this investigation. They are also indebted to the several producers of dextran, and to the staff of the Northern Regional Research Laboratory, U. S. Department of Agriculture, for providing samples of dextran, analytical methods and data. The collaboration of S. G. Weissberg and his associates at the Bureau has been most helpful and is gratefully acknowledged.

\section{References}

[1] H. L. A. Tarr and H. Hibbert, Can. J. Research 5, 414 (1931).

[2] T. H. Evans and H. Hibbert, (Bacterial Polysaccharides) Advances in Carbohydrate Chemistry, 2, p. 203, (Academic Press, Inc., New York, N. Y., 1946).

[3] M. Stacey, (The Chemistry of Mucopolysaccharides and Mucoproteins), Advances in Carbohydrate Chemistry, 2, p. 161, (Academic Press, Inc., New York, N. Y., 1946).

[4] A. Jeanes, Dextran -a selected bibliography, U. S. Department of Agriculture, Northern Regional Research Laboratory, Peoria, Illinois (1950).

[5] A. Grönwall and B. Ingelman, Nature 155, 45 (1945).

[6] K. H. Meyer, G. Noelting, and P. Bernfeld, Helv. Chim. Acta 31, 103 (1948).

[7] H. S. Isbell, W. W. Pigman, and H. L. Frush, J. Research NBS 24, 241 (1940) RP1282. 
[8] H. S. Isbell, Report of working conference on dextran, Peoria, Ill., July 9, 1951, sponsored by National Research Council, Subcommittee on Shock and Northern Regional Research Laboratory.

[9] S. G. Weissberg and H. S. Isbell, Molecular properties of plasma substitutes, NBS Report 1160 (Sept. 24, 1951).

[10] H. S. Isbell, Science 113, 532 (1951).

[11] M. Somogyi, J. Biol. Chem. 160, 61 (1945).

[12] Memorandum No. B-50, Commercial Solvents Corporation, Terre Haute, Indiana, Determination of numberaverage molecular weight of dextran by end-group analysis, January 1952.
[13] Polarimetry, saccharimetry and the sugars, NBS Circular C440, p. 463 (1942).

[14] M. Somogyi, J. Biol. Chem. 70, 599 (1926).

[15] Official Methods of Analysis of the Association of Official Agricultural Chemists, 7th ed., p. 513 (1950).

[16] O. Folin and H. Wu, J. Biol. Chem. 38, 106 (1919).

[17] War Department Technical Manual, TM 8-227, U. S. Government Printing Office, Washington, D. C. (1946).

Washington. November 14, 1952. 